\title{
The False KILlen WHALE (PSEUDORCa CRASSIDENS) IN THE SOUTHWESTERN CARIBBEAN: FIRST STRANDING RECORD IN COLOMBIAN WATERS ${ }^{1}$
}

\author{
Mario A. Pardo ${ }^{2,}$, Cristina Jiménez-Pinedo ${ }^{2}$ and Daniel M. Palacios ${ }^{3,4}$
}

The false killer whale (Pseudorca crassidens) exhibits one of the widest and most continuous distributions among cetaceans, inhabiting tropical and subtropical oceanic waters around the world (Jefferson et al., 1993). However, basic information about its biology is scarce due to the low frequency of sightings and its offshore habits. For this reason, most of the knowledge of this species has been obtained from stranded animals (Odell and McClune, 1999). In the Western Atlantic, it is common from Cape Hatteras, USA, to Tierra del Fuego, Argentina (Stacey et al., 1994). Although it has been suggested that this range includes the Caribbean Sea (Odell and McClune, 1999), there are few reports for this basin. According to recent reviews (Romero et al., 2001; Ward et al., 2001), P. crassidens has been mainly recorded in the northeastern and eastern Caribbean (Antigua, Cuba, Dominica, Grenada, the Grenadines, Puerto Rico, Saint Lucia, Saint Vincent, Tobago, the Virgin Islands, and Venezuela). Only one sighting has been reported for the western Caribbean (Palacios et al., 19955 , 19966 ; Pardo et al., 2009), and there are no records for its southwestern portion.

This note documents the first record of a stranding of $P$. crassidens in the Colombian Caribbean, and describes in detail the skull morphology of the specimen. The stranding occurred in June 2001 in the Santuario de Fauna y Flora Los Flamencos (SFFLF), a national natural reserve located $23 \mathrm{~km}$ southwest of the city of Rioacha (Figure 1). Park personnel buried the carcass and later recovered the partial skeleton, which was stored at the SFFLF facilities. We examined the remains in February 2006. The specimen (Figure 2) was identified as $P$. crassidens based on the characteristics described by Purves and Pilleri (1978), Ross (1984), Jefferson et al. (1993), Stacey et al. (1994), and Odell and McClune (1999). The skull measured $61.8 \mathrm{~cm}$ in condylobasal length (CBL), which together with the complete fusion of the cranial bones, suggests that it belonged to an adult specimen (Ross, 1984). The width of the skull between the squamosal processes was more than the $50 \%$ of the CBL. Only 26 teeth were found of the 35 possible (from count of the alveoli in the maxillaries and mandibles). The total length of the skeleton from the tip of the skull to the last of the 42 vertebrae was $4.37 \mathrm{~m}$. The remains examined included 11 pairs of ribs and the two scapulae. The sternum, flipper bones, tympanic bullae, and middle ear bones were missing.

A craniometry was performed based on 34 parameters following Perrin (1975), Schnell et al. (1985) and Van Waerebeek et al. (1990) (Table 1, Figure 3). Measurements were taken at the SFFLF facilities with the aid of a metric ruler and calipers (with a precision of $\pm 1 \mathrm{~mm}$ and $\pm 0.1 \mathrm{~mm}$, respectively). The procedure was repeated in the laboratory from digital photographs using the software SigmaScanPro $4.0^{\circledR}$ to include additional craniometric characters missed in the field. Because there were no significant differences between the digital and field measurements, here we report only the digital data for the complete set (Table 1). After examination, the skull was deposited in the zoological collection of the SFFLF.

Selected skull dimensions, considered as a percentage of the CBL, were compared with the ranges reported previously for adult specimens from other areas, and by sex categories. We used data from skulls of two individuals from southeastern Africa (Ross, 1984), the mean values from a mass stranding in Florida (Odell and McClune, 1999), and the mean values for the species reported by Purves and Pilleri (1978). The skull proportions were similar among specimens. The specimen in this study showed slightly lower proportions for the length of the rostrum (measurement \#2 in Table 1) and the length of the tooth row (\#31), and a proportionally wider skull (\#14), but in general, there were no great differences with those from the literature (Figure 4).

\footnotetext{
${ }^{1}$ Received on 25 April 2008. Accepted on 12 August 2008. Managed by Nélio Barros.

2 Instituto Politécnico Nacional, Centro Interdisciplinario de Ciencias Marinas, Laboratorio de Ecología de Cetáceos y Quelonios. Av. IPN s/n Col. Playa Palo de Santa Rita 23096, La Paz, BCS, Mexico.

* Corresponding author, e-mail: mpardor0600@ipn.mx.

${ }^{3}$ Joint Institute for Marine and Atmospheric Research, University of Hawaii, 1000 Pope Road, MSB 312, Honolulu, HI 96822, USA

${ }^{4}$ NOAA, NMFS, Southwest Fisheries Science Center, Environmental Research Division. 1352 Lighthouse Avenue, Pacific Grove, CA 93950-2097, USA.

${ }^{5}$ Palacios, D.M., Gerrodette, T., Beltrán, S., Rodriguez, P. and Brennan, B. (1995) Cetacean sighting cruises off the Colombian Caribbean Sea and Pacific Ocean. Page 88 in Abstracts, Eleventh Biennial Conference on the Biology of Marine Mammals, 14-16 December 1995, Orlando, Florida, USA.

${ }^{6}$ Palacios, D.M., Rodríguez, P., Brennan, B.J., Beltrán, S., and Trujillo, F. (1996) Cetacean sightings during cruises in the southwestern Caribbean Sea. Page 76 in Programas y Resumenes, 7ma. Reunión de Trabajo de Especialistas en Mamíferos Acuáticos de América del Sur, 22-25 October 1996, Viña del Mar, Chile.
} 


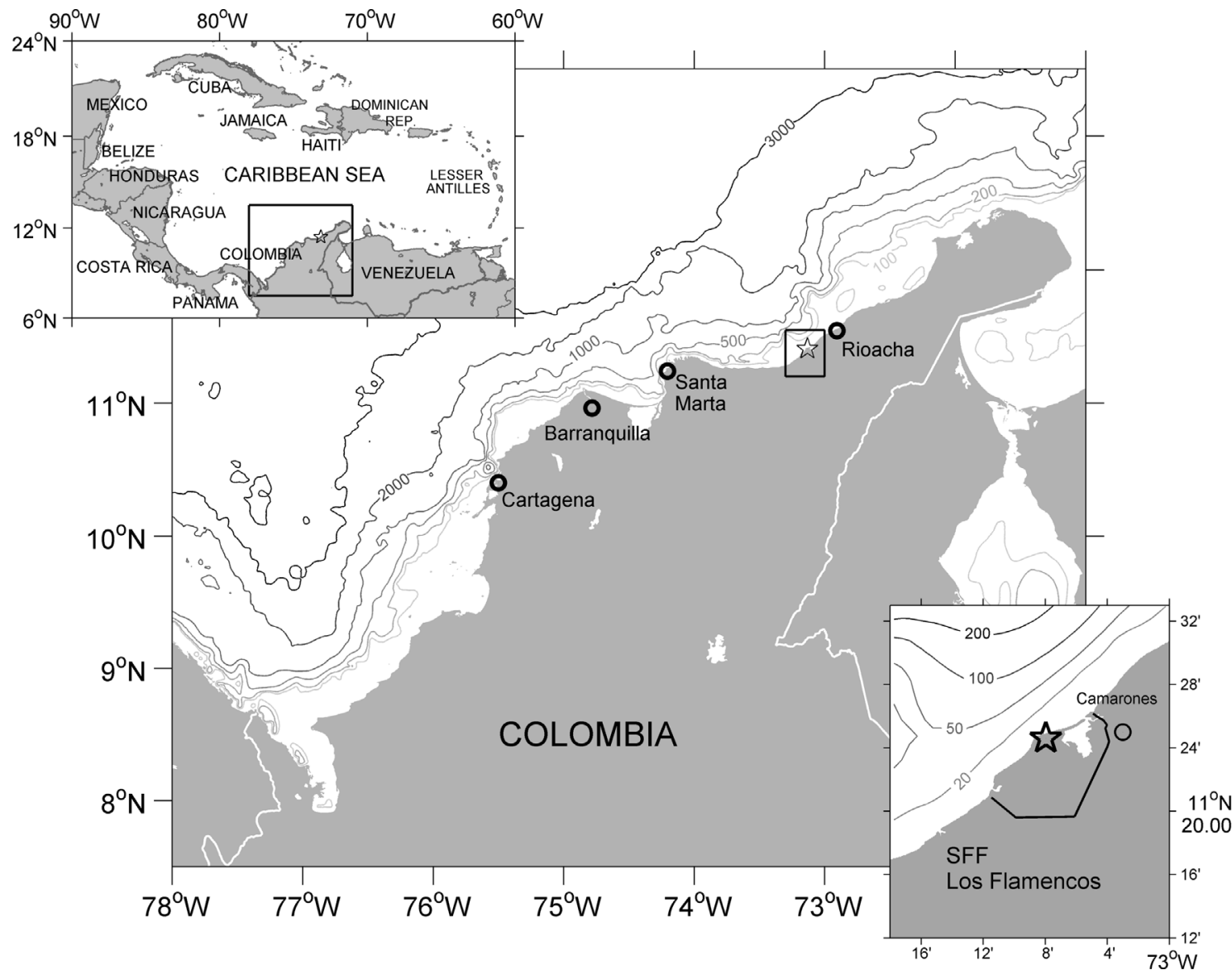

Figure 1. Coastline and major cities of Colombia in the southwestern Caribbean. Inset shows the boundaries of the Santuario de Fauna y Flora Los Flamencos (SFFLF) and the town of Camarones, not far from the stranding site (marked with a star). Selected bathymetric contours are shown (source: SRTM30_PLUS global topography v.3.0, available from http://topex.ucsd.edu/).

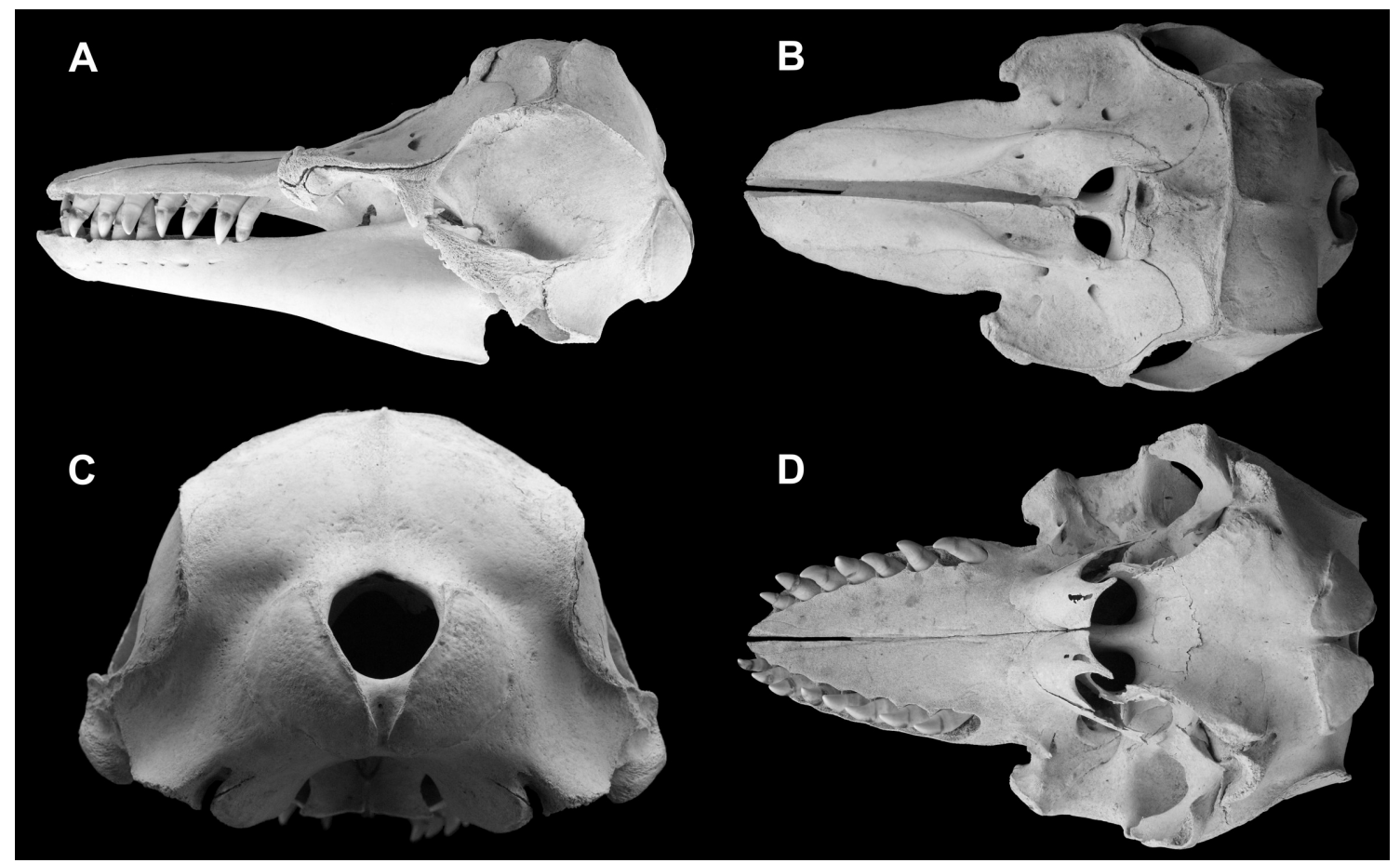

Figure 2. Skull of Pseudorca crassidens found in June 2001 in the SFFLF, Colombian Caribbean. Views: (A) left side, (B) dorsal, (C) posterior, and (D) ventral. Images are not at the same scale. Photographs by C. Domínguez. 
Table 1. Skull measurements (in mm) for Pseudorca crassidens specimen found in June 2001 in the Santuario de Fauna y Flora Los Flamencos (SFFLF), Colombian Caribbean. Measurement numbers correspond to those portrayed in Figure 3.

\begin{tabular}{|c|c|c|c|}
\hline No. & MEASUREMENT & LENGTH $(\mathrm{mm})$ & $\%$ of $\mathrm{CBL}$ \\
\hline 1 & Condylobasal length & 618.0 & 100 \\
\hline 2 & Length of rostrum & 271.7 & 44.0 \\
\hline 3 & Width of rostrum at base & 195.4 & 31.6 \\
\hline 4 & Width of rostrum at $1 / 4$ length & 195.7 & 31.7 \\
\hline 5 & Width of rostrum at $1 / 2$ length & 175.3 & 28.4 \\
\hline 6 & Width of premaxillaries at $1 / 2$ length of rostrum & 126.2 & 20.4 \\
\hline 7 & Width of rostrum at $3 / 4$ length & 147.2 & 23.8 \\
\hline 8 & Dorsal distance from tip of rostrum to internal nares & 334.0 & 54.0 \\
\hline 9 & Ventral distance from the tip of rostrum to internal nares & 338.7 & 54.8 \\
\hline 10 & Greatest preorbital width & 331.4 & 53.6 \\
\hline 11 & Greatest posorbital width & 366.3 & 59.3 \\
\hline 12 & Least supraorbital width & 329.0 & 53.2 \\
\hline 13 & Greatest width of external nares & 93.2 & 15.1 \\
\hline 14 & Greatest width across zygomatic processes of squamosal & 418.6 & 67.7 \\
\hline 15 & Greatest width of premaxillaries & 138.3 & 22.4 \\
\hline 16 & Greatest parietal width & 257.4 & 41.7 \\
\hline 17 & Vertical external height of braincase & 216.5 & 35.0 \\
\hline 18 & Greatest length of left posttemporal fossa & 214.1 & 34.6 \\
\hline 19 & Greatest width of left postemporal fossa & 146.0 & 23.6 \\
\hline 20 & Projection of premaxillaries beyond maxillaries & 17.0 & 2.8 \\
\hline 21 & $\begin{array}{l}\text { Distance from foremost end of junction between nasal to hindmost point of margin } \\
\text { of supraoccipital crest }\end{array}$ & 36.5 & 5.9 \\
\hline 22 & Length of left orbit-from apex of preorbital process to apex of post-orbital process & 91.9 & 14.9 \\
\hline 23 & Length of antorbital process of left lacrimal & 63.6 & 10.3 \\
\hline 24 & Greatest width of internal nares & 98.2 & 15.9 \\
\hline 25 & Greatest length of left pterygoid & 83.5 & 13.5 \\
\hline 26 & Length of upper left tooth row & 252.0 & 40.8 \\
\hline 27 & Number of teeth - upper left & 9 (alveoli) & - \\
\hline 28 & Number of teeth - upper right & 8 (alveoli) & - \\
\hline 29 & Number of teeth - lower left & 9 (alveoli) & - \\
\hline 30 & Number of teeth - lower right & 10 (alveoli) & - \\
\hline 31 & Length of lower left tooth row & 444.2 & 71.9 \\
\hline 32 & Greatest length of left ramus & 220.6 & 35.7 \\
\hline 33 & Greatest height of left ramus & 122.0 & 19.7 \\
\hline 34 & Deviation of skull from symmetry in dorsal view & $18.2^{\circ}$ & - \\
\hline
\end{tabular}

With this report, we validate occurrence of the species in Colombian waters and add the southwestern Caribbean to the confirmed range of $P$. crassidens. It joins 16 other cetacean species that have been reported for the Colombian Caribbean region: humpback whale (Megaptera novaeangliae), ordinary Bryde's whale (Balaenoptera brydei), fin whale (Balaenoptera physalus), sperm whale (Physeter macrocephalus), dwarf sperm whale (Kogia sima), pygmy sperm whale (Kogia breviceps), Cuvier's beaked whale (Ziphius cavirostris), Gervais' beaked whale
(Mesoplodon europaeus), rough-toothed dolphin (Steno bredanensis), Guiana dolphin (Sotalia guianensis), common bottlenose dolphin (Tursiops truncatus), pantropical spotted dolphin (Stenella attenuata), Atlantic spotted dolphin (Stenella frontalis), striped dolphin (Stenella coeruleoalba), short-beaked common dolphin (Delphinus delphis), Risso's dolphin (Grampus griseus), and the short-finned pilot whale (Globicephala macrorhynchus) (Vidal, 1990; Flórez-González and Capella, 1995; Flórez-González et al., 2004; Pardo and Palacios, 2006). 


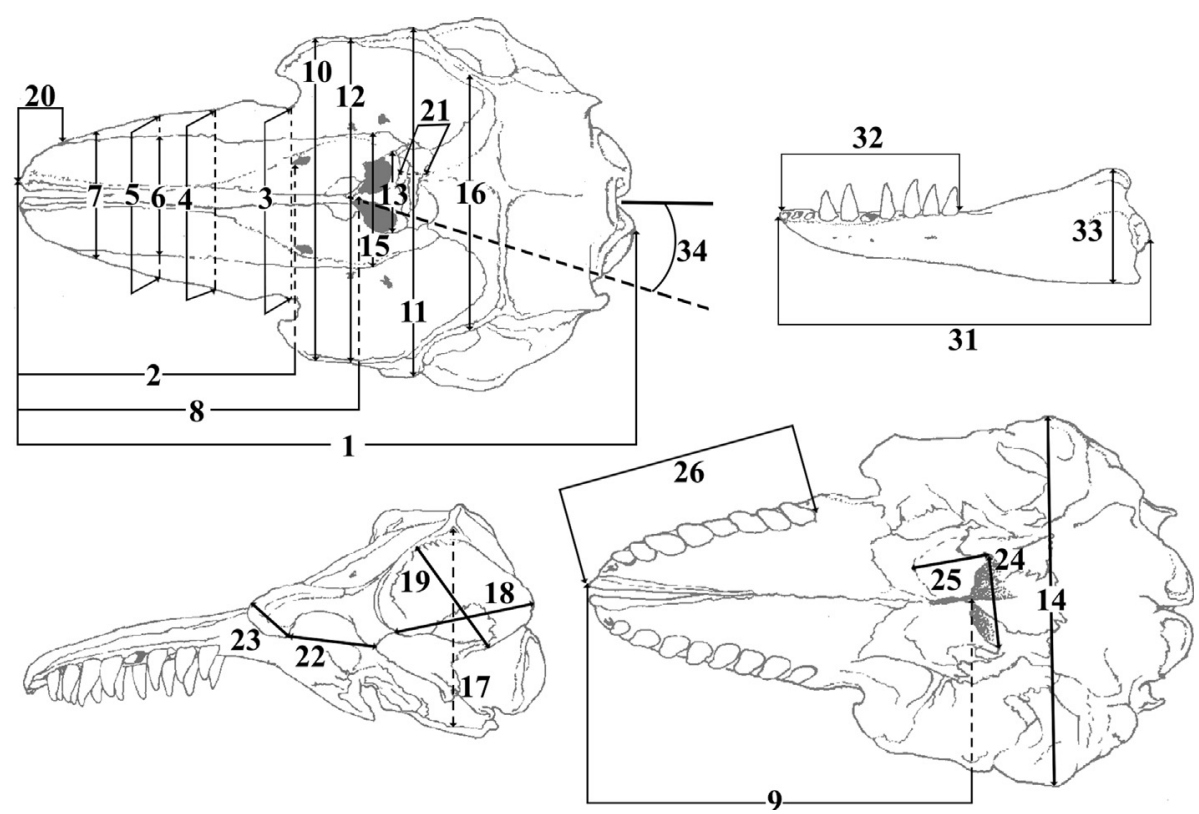

Figure 3. Schematic views of the skull measurements. Parameter numbers correspond to those in Table 1. Base contours were modified from Jefferson et al. (1993).
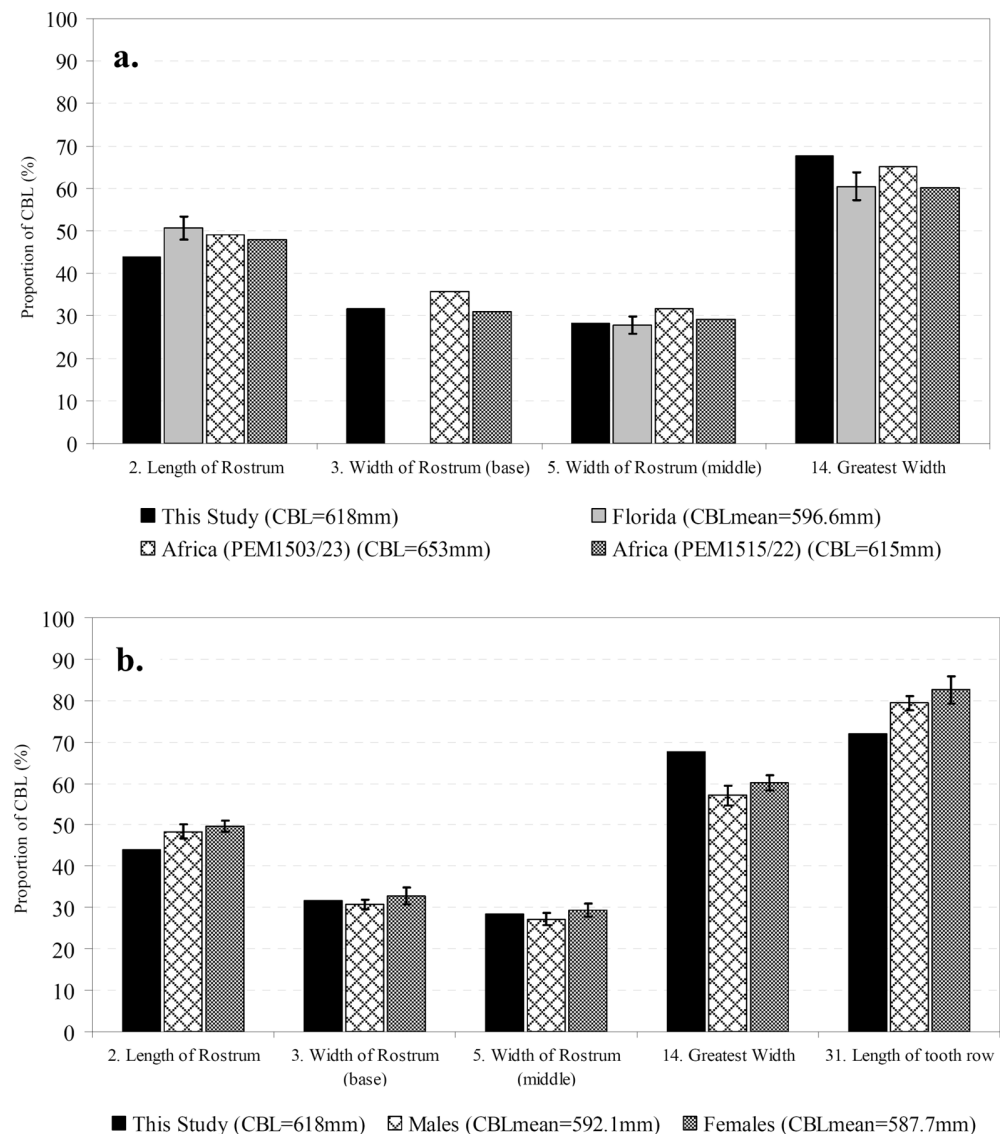

Figure 4. Comparison of some skull proportions, expressed as a percentage of the CBL, between the specimen in this study and others reported in the literature. The numbers along the x-axis correspond to the parameters referred to in Table 1 and Figure 3 . Standard deviation is presented where available. a. Values for two individuals from Africa (specimen codes in parentheses; Ross, 1984) and the mean values from Florida ( $\mathrm{n}=24$ for \#2 and \#5; $\mathrm{n}=21$ for \#14; Odell and McClune, 1999). $\mathbf{b}$. Mean proportions for males $(\mathrm{n}=42$ for \#s 2 , 3, 5, and 14; $\mathrm{n}=35$ for \#31) and females ( $\mathrm{n}=34$ for \#s 2, 3, and 5; $\mathrm{n}=33$ for \#14; and $\mathrm{n}=31$ for \#31) (Purves and Pilleri, 1978). 
The occurrence of other species, such as the pygmy killer whale (Feresa attenuata) and the melon-headed whale (Peponocephala electra), might be expected based on findings in nearby Venezuelan (Bolaños and Villarroel-Marin, 2003) and Netherlands Antilles (Debrot et al., 1998) waters, respectively. Therefore, is important to continue to properly document and report new records for areas such as the Colombian Caribbean, for which little information is available.

\section{Acknowledgments}

The authors would like to acknowledge the support provided by the SFFLF, its director Laura Guerrero, and the Unidad de Parques Nacionales de Colombia. The fieldwork was supported by Carolina Domínguez (Universidad de Bogotá Jorge Tadeo Lozano, Colombia) and Elder Páramo (SFFLF). Jorge Urbán (Universidad Autónoma de Baja California Sur, Mexico) provided access to relevant literature. Useful comments on an earlier version of the manuscript were kindly provided by Antonio Mignucci-Giannoni, Adolphe Debrot, Marcos Santos, Koen Van Waerebeek, and Norman Silverberg.

\section{References}

Bolaños, J AND Villarroel-Marin, A. (2003) Three new records of cetacean species for Venezuelan Waters. Caribbean Journal of Science 39(2): 230-232.

Debrot, A.O., De Meyer, J.A. And Dezentjé, P.J.E. (1998) Additional records and the review of the cetacean fauna of the Leeward Dutch Antilles. Caribbean Journal of Science 34(34): 204-210.

Flórez-González, L., Capella, J. And Falk, P. (2004) Guía de campo de los mamíferos acuáticos de Colombia. Third edition. Editorial Sepia Ltda., Cali, Colombia, 124 pp.

FlóREZ-GonzÁlez, L. ANd CAPELlA, J. (1995) Mamíferos acuáticos de Colombia. Una revisión y nuevas observaciones sobre su presencia, estado del conocimiento y conservación. Informe del Museo del Mar (Universidad Jorge Tadeo Lozano, Bogotá, Colombia) (39): 1-29.

Jefrerson, T., Leatherwood, S. and Webber, M. (1993) Marine Mammals of the World. FAO Species Identification Guide. Rome, Italy. 320pp.

Mora-Pinto, D.M., Muñoz-Hincapié, M.F., Mignucci-Giannoni,
A.A. AND ACERo-Pizarro, A. (1995) Marine mammal mortality and strandings along the Pacific coast of Colombia. Reports of the International Whaling Commission 45: 427-429.

Odell, D.K. And McClune, K.M. (1999) Pseudorca crassidens (Owen, 1846). Pages 213-244 in Ridgway, S.H. AND HARRISON, S.R. (Eds) Handbook of Marine Mammals Vol. 6: The Second Book of Dolphins and Porpoises. Academic Press, London, United Kingdom.

Pardo, M.A. And PAlacios, D.M. (2006) Cetacean occurrence in the Santa Marta region, Colombian Caribbean, 2004-2005. Latin American Journal of Aquatic Mammals 5(2): 129-134.

Pardo, M.A, Mejía-Fajardo, A., Beltrán-Pedreros, S., Trujillo, F., Kerr, I. ANd Palacios, D.M. (2009) Odontocete sightings collected during offshore cruises in the southwestern and western Caribbean Sea. Latin American Journal of Aquatic Mammals 7(1-2): 57-62.

PERRIN, W.F. (1975) Variation of spotted and spinner porpoise (genus Stenella) in the Eastern Pacific and Hawaii. Bulletin of the Scripps Institution of Oceanography 21: 1-206.

Purves, P.E. And Pilleri, G. (1978) The functional anatomy and general biology of Pseudorca crassidens (Owen) with a review of the hydrodynamics and acoustics in Cetacea. Investigations on Cetacea 9: 67-227.

Romero, A., Agudo, A.I., Green, S.M. and Notarbartolo di SCIARA, G. (2001) Cetaceans of Venezuela: their distribution and conservation status. NOAA Technical Report NMFS 151: 1-60.

Ross, G.J.B. (1984) The smaller cetaceans of the south east coast of southern Africa. Annals of the Cape Provincial Museums, Natural History 15(2): 173-410.

Schnell, G.D., Douglas, M.E. And Hough, D.J. (1985) Sexual dimorphism in spotted dolphins (Stenella attenuata) in the eastern tropical Pacific Ocean. Marine Mammal Science 1(1): 1-14.

Stacey, P.J., Leatherwood, S. And Baird, R.W. (1994) Pseudorca crassidens. Mammalian Species 456: 1-6.

Van Waerebeek, K., Reyes, J.C., Read, A.J. and McKinnon, J.F. (1990) Preliminary observations of bottlenose dolphins from the Pacific coast of South America. Pages 143-154 in Leatherwood, S. And Reeves, R. (Eds) The Bottlenose Dolphin. Academic Press, San Diego, CA, USA. 653pp.

VIDAL, O. (1990) Lista de los mamíferos acuáticos de Colombia. Informe del Museo del Mar (Universidad Jorge Tadeo Lozano, Bogotá, Colombia) (37): 1-18.

Ward, N., Moscrop, A. AND CARlson, C. (2001) Elements for the Development of a Marine Mammal Action Plan for the Wider Caribbean: A Review of Marine Mammal Distribution. UNEP (DEC)/CAR IG.20/INF 3. 